\title{
Developmental coordination disorder and migraine in childhood
}

\author{
M Esposito ${ }^{1 *}$, MA Faraldo $^{2}$, L Antinolfi $^{2}$, M Carotenuto $^{2}$ \\ From The European Headache and Migraine Trust International Congress \\ London, UK. 20-23 September 2012
}

\section{Purpose}

Migraine without aura (MoA) could be considered the most frequent form of primary headache in children, associated with many known comorbidities, but only the recent literature has begun to consider the importance of motor impairment linked to the attacks. The developmental coordination disorder (DCD) is a very common problem among children, with a prevalence ranging up to $19 \%$. The aim of this study was to evaluate the presence of motor coordination impairment in a population of children affected by MoA, and its role as putative risk factor for motor skills impairment.

\section{Methods}

This observational study was performed in the Clinic of Child and Adolescent Neuropsychiatry of the Second University of Naples. MoA was diagnosed according to the International Classification of Headache Disorders (IHS-2) criteria. The study population consisted of 27 patients affected by MoA (16 females, 11 males) (mean age: $8.7 \pm$ 2.15 years) and 59 typically developing children (34 females, 25 males) (mean age: $8.0 \pm 2.1$ years). The whole population underwent a clinical evaluation in order to assess the Total IQ level, the visual motor integration skills and the presence of DCD.

\section{Results}

Our results showed that MoA children had more impairments in motor coordination $(\mathrm{p}<0.001)$ and visual motor integration $(\mathrm{p}<0.001)$ than control group.

\section{Conclusion}

To our knowledge this is the first study to assess the association of poor motor coordination and MoA in children using.

${ }^{1}$ Department of Child and Adolescent Neuropsychiatry, Italy

Full list of author information is available at the end of the article

\section{Objective measurements}

These findings suggest a new perspective in the management of migraine disease in children, pinpointing that the relationship between DCD and migraine could represent a not yet understood or identified comorbidity, even if further reports are necessary, and that migraine probably could be considered not only a painful syndrome in future.

\section{Author details}

${ }^{1}$ Department of Child and Adolescent Neuropsychiatry, Italy. ${ }^{2}$ Department of Child and Adolescent Neuropsychiatry, Italy.

Published: 21 February 2013

\section{References}

1. Cairney J, Kwan MY, Hay JA, Faught BE: Developmental Coordination Disorder, gender, and body weight: Examining the impact of participation in active play. Res Dev Disabil 2012, 33(5):1566-1573.

2. Headache Classification Subcommittee of the International Headache Society: The International Classification of Headache Disorders. Cephalalgia , 2 2004, 24(Suppl 1):9-160.

doi:10.1186/1129-2377-14-S1-P14

Cite this article as: Esposito et al:: Developmental coordination disorder and migraine in childhood. The Journal of Headache and Pain 2013 14(Suppl 1):P14.

Submit your manuscript to a SpringerOpen ${ }^{\circ}$ journal and benefit from:

- Convenient online submission

- Rigorous peer review

- Immediate publication on acceptance

- Open access: articles freely available online

- High visibility within the field

- Retaining the copyright to your article

Submit your next manuscript at $>$ springeropen.com
SpringerOpen ${ }^{\odot}$

(c) 2013 Esposito et al; licensee Springer. This is an Open Access article distributed under the terms of the Creative Commons Attribution License (http://creativecommons.org/licenses/by/2.0), which permits unrestricted use, distribution, and reproduction in any medium, provided the original work is properly cited. 